\title{
PERAN KEPUASAN KERJA SEBAGAI VARIABEL MEDIASI PENGARUH BUDAYA ORGANISASI TERHADAP KINERJA KARYAWAN
}

Abdul Komar^

\begin{abstract}
The purpose of this research is to explain the influence of organizational culture on job satisfaction, the influence of organizational culture on employee performance, the effect of job satisfaction on employee performance and the role of job satisfaction as a mediating variable influence organizational culture on employee performance. This type of research is qualitative research that uses literature studies, in which it examines the influence between variables based on existing theoretical theories and is reinforced by empirical studies of relevant journal journals. The results of this study indicate that organizational culture has a positive effect on job satisfaction, organizational culture has a positive effect on employee performance, job satisfaction has a positive effect on employee performance and organizational culture has a positive effect on employee performance through job satisfaction.
\end{abstract}

Keywords: organizational culture; Job satisfaction ; Employee performance

• Dosen Tetap Fak. Tarbiyah INZAH Genggong Kraksaan 


\section{PENDAHULUAN}

Sumber daya manusia harus dikelola dengan sangat baik guna meningkatkan efektivitas dan efisiensi suatu organisasi. Sumberdaya manusia ini pada dasarnya memegang peranan yang sangat penting dalam keberhasilan suatu organisasi, jadi seumberdaya manusia harus dikelola dengan baik karena hal tersebut merupakan faktor kunci agar organisasi dapat mencapai tujuannya. Pendayagunaan sumberdaya manusia secara efektif dan efisien akan dapat membantu organisasi untuk dapat lebih berkembang menjadi lebih besar. Sumberdaya manusia adalah sekumpulan rancangan sistem yang terstruktur dalam sebuah organisasi untuk memastikan penggunaan bakat manusia secara efektif dan efisien untuk mencapai tujuan dari organisasi ${ }^{1}$. Berdasarkan pengertian tersebut dapat diketahui bahwa sumberdaya manusia yang dimiliki oleh sebuah organisasi harus bisa digunakan secara efektif dan efisien agar tujuan organisasi dapat tercapai dengan baik. Kualitas sumberdaya manusia yang dimiliki oleh organisasi dapat diukur baik atau buruknya berdasarkan kinerjanya dalam menyelesaikan pekerjaannya guna mencapai tujuan organisasi itu sendiri. Kinerja adalah sebagai hasil kerja secara kualitas dan kuantitas yang dapat dicapai oleh seseorang karyawan dalam melaksanakan tugas sesuai dengan tanggung jawab yang diberikan kepadanya ${ }^{2}$. Terdapat banyak factor yang mempengaruhi kinerja.salah satunya adalah kepuasan kerja.

Kepuasan kerja merupakan keadaan emosional yang menyenangkan atau tidak menyenangkan saat karyawan memandang pekerjaannya ${ }^{3}$. Kepuasan kerja memiliki pengaruh yang kuat terhadap kinerja karyawan, apabila karyawan memiliki kepuasan kerja yang tinggi maka akan berdampak sangat

\footnotetext{
${ }^{1}$ Mathis, R. L., dan J.H. Jackson., Manajemen Sumber Daya Manusia, (Jakarta: Salemba Empat, 2006), Halaman : 3

${ }^{2}$ Mangkunegara, Aa. Anwar Prabu, Manajemen Sumber Daya Manusia Perusahaan ( Bandung: Rosda, 2008), Halaman : 103

${ }^{3}$ Handoko, T. Hani, Manajemen Personalia dan Sumber Daya Manusia ( Yogyakarta: BPFE, 2014), Halaman :193
} 
baik terhadap kinerjanya, begitu pula sebaliknya. Karyawan akan merasa tidak puas apabila karyawan itu sendiri merasa apa yang telah dikerjakannya tidak sebanding dengan apa yang diperoleh dari organisasi tempatnya bekerja. Ketidakpuasan ini akan ditunjukkan dengan sikap negatif karyawan terhadap organisasi seperti tingkat absensi tinggi dan tingkat turnover juga tinggi sehingga menyebabkan terhambatnya pencapaian tujuan organisasi. Faktor lain yang mempengaruhi kinerja adalah budaya organisasi.

Budaya organisasi adalah suatu pola asumsi dasar yang diciptakan oleh organisasi sebagai pembelajaran untuk memecahkan masalah adaptasi lingkungan eksternal dan integrasi internal serta dapat terlaksana dengan baik $^{4}$. Oleh karena itu harus diajarkan kepada angota-anggota baru organisasi sebagai cara yang tepat untuk memahami, memikirkan dan merasakan masalah-masalah yang dihadapi oleh organisasi tersebut. Budaya organisasi yang baik akan menyebabkan kepuasan kerja karyawan semakin tingi sehingga kinerjanya juga akan semakin tinggi, akhirnya tujuan organisasi dapat tercapai.

\section{A. Kerangka Konseptual}

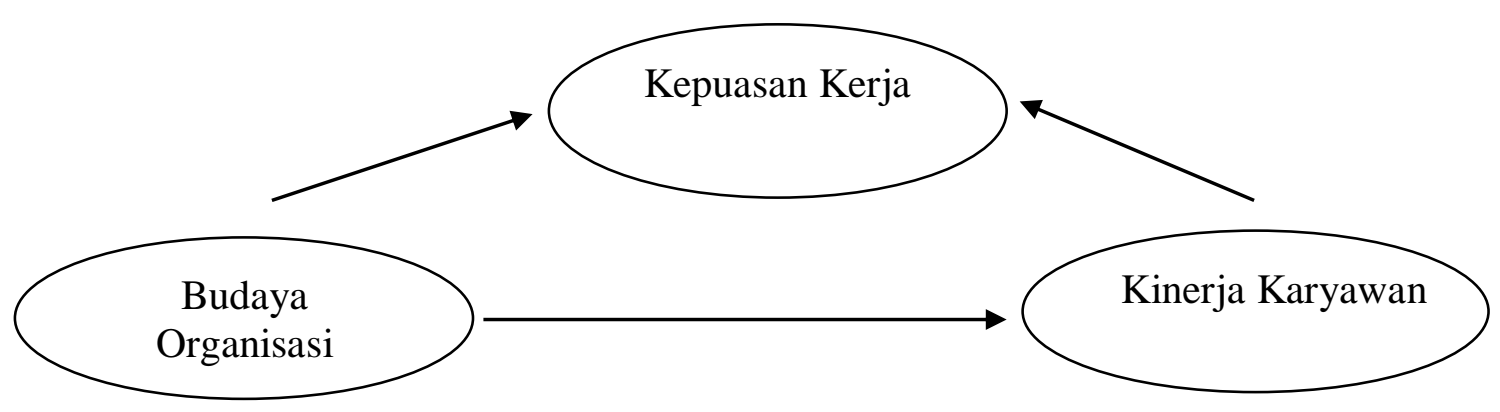

${ }^{4}$ Schein, Edgar H, Organizational Culture and Leadership ( San Fransisco : Bass Publishers, 2004), Halaman 17 


\section{PEMBAHASAN}

\section{Pengaruh Budaya Organisasi terhadap Kepuasan Kerja}

Budaya organisasi adalah suatu pola asumsi dasar yang diciptakan oleh organisasi sebagai pembelajaran untuk memecahkan masalah adaptasi lingkungan eksternal dan integrasi internal serta dapat terlaksana dengan baik $^{5}$. Oleh karena itu h5arus diajarkan kepada angota-anggota baru sebagai cara yang tepat untuk memahami, memikirkan dan merasakan masalah-masalah yang dihadapi tersebut. Budaya organisasi berkaitan dengan bagaimana para karyawan mempersepsikan karakteristik dari suatu budaya organisasi, bukan dengan apakah para karyawan menyukai budaya tersebut atau tidak.

Menurut Schein (dalam Herawan) Budaya organisasi dapat menyebabkan kepuasan individual yang dimanifestasikan dalam bentuk pertemuan dan komunikasi antar pribadi yang efektif, keberhasilan sosialisasi individu, dan peningkatan produktivitas kerja ${ }^{6}$. Berdasarkan pernyataan tersebut kita dapat mengetahui bahwa budaya organisasi yang dibuat oleh organisasi memiliki tujuan untuk memberikan semangat terhadap karyawannya dalam bekerja sehingga karyawan akan merasa nyaman dalam menyelesaikan pekerjaannya dengan baik. Selanjutnya, perusahaan akan memberikan balas jasa yang sesuai dengan hasil kerja karyawan tersebut dan karyawan akan merasa puas. Semakin tinggi budaya organisasi yang dianut oleh karyawan maka kepuasan kerja karyawan akan semakin tinggi pula sesuai dengan penelitian yang

\footnotetext{
${ }^{5}$ Ibid.,hlm.2

${ }^{6}$ Herawan, K., M. D. Mukzam dan G. E. Nurtjahjono, Pengaruh Budaya Organisasi terhadap Kepuasan Kerja Karyawan Studi pada PT. Bank Rakyat Indonesia (Persero) Kantor Cabang Kota Malang Kawi (Jurnal Administrasi Bisnis, 2015), Volume 1(1), Halaman : 1-6
} 
dilakukan oleh Wahyuniardi dan Nurjaman ${ }^{7}$ serta Prahasti dan Wahyono ${ }^{8}$, yang menyatakan bahwa budaya organisasi berpengaruh positif dan signfikan terhadap kinerja karyawan. Artinya semakin tinggi budaya organisasi yang dianut oleh karyawan maka kinerja karyawan akan semakin tinggi pula.Sebaliknya semakin rendah budaya organisasi yang dianut oleh karyawan maka kinerja karyawan akan semakin rendah pula.

\section{Pengaruh Budaya Organisasi terhadap Kinerja karyawan}

Robbin (dalam Mangkunegara) menggambarkan hubungan antara komunikasi, budaya perusahaan yang berdampak pada kinerja karyawan sebagaimana tertera pada gambar dibawah ini ${ }^{9}$ :

Gambar 1. Hubungan antara budaya perusahaan dan kinerja karyawan

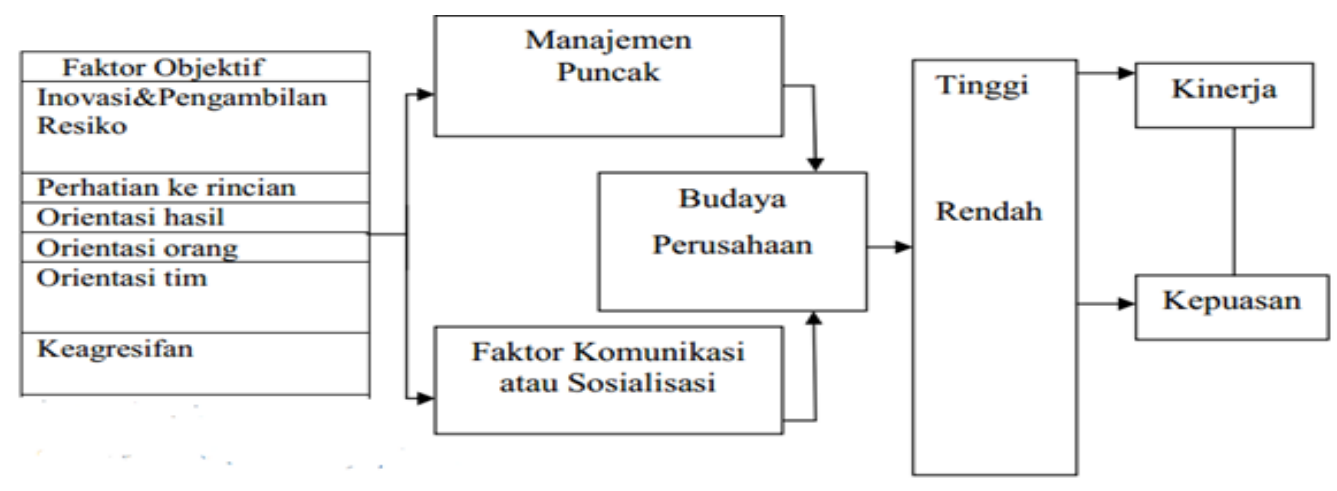

Berdasarkan gambar diatas kita dapat mengetahui bahwa pembentukan kinerja yang baik dapat tercapai jika terdapat komunikasi

\footnotetext{
${ }^{7}$ Wahyuniardi, Rizki., Nurjaman, Sidik., Pengaruh Budaya Organisasi dan Lingkungan Kerja Terhadap Kepuasan Kerja dan Kinerja Karyawan. (Jurnal Optimasi Sistem Industri, 2018), Volume 17 No. 2, Halaman : 143-151

${ }^{8}$ Prahasti, Shella., Wahyono, Pengaruh Gaya Kepemimpinan, Budaya Organisasi, dan Lingkungan Kerja terhadap Kinerja Pegawai dengan Kepuasan Kerja Sebagai Mediator ( Economic Education Analysis Journal, 2019), Volume7(2), Halaman : 543-552

${ }^{9}$ Ibid.,hlm.2
} 
antara seluruh karyawan sehingga dapat membentuk internalisasi budaya perusahaan yang kuat dan dipahami sesuai dengan nilai-nilai organisasi yang dapat menimbulkan persepsi positif antara semua tingkatan karyawan untuk mendukung dan mempengaruhi iklim kepuasan yang berdampak pada kinerja karyawan. Penelitian yang dilakukan

oleh Fadude et $a l^{10}$., Kurniawati ${ }^{11}$ dan Susanti ${ }^{12}$ yang menyatakan bahwa budaya organisasi berpengaruh positif terhadap kinerja yang artinya budaya organisasi yang ada di perusahaan memiliki pengaruh yang baik sehingga dapat meningkatkan kinerja karyawan.

\section{Pengaruh Kepuasan Kerja terhadap Kinerja Karyawan}

Salah satu ciri individu yang memiliki motivasi berprestasi tinggi untuk mencapai kinerja adalah individu yang memperoleh sedikit kepuasan jika pekerjaannya sangat mudah ${ }^{13}$. Hal ini berarti, seseorang dengan kepuasan kerja yang tinggi akan semakin tinggi pula kinerjanya dalam menyelesaikan pekeerjannya. Karyawan dengan kepuasan kerja yang tinggi akan semakin termotivasi untuk lebih semangat dalam bekerja dan berusaha untuk memberikan yang terbaik untuk organisasi tempatnya bekerja karena merasa dihargai oleh organisasi. Sebaliknya, karyawan yang mengalami ketidakpuasan dalam bekerja akan memberikan hasil kerja yang kurang baik sehingga kinerja dari karyawan itu sendiri akan menurun sesuai dengan hasil penelitian yang Purba et al. ${ }^{14}$ dan Susanto ${ }^{15}$

\footnotetext{
${ }^{10}$ Fadude ,Fikri Djafar, Tawas, Hendra N, Poluan, Jane Grace.Pengaruh Budaya Organisasi dan Iklim Organisasi terhadap Kinerja Pegawai (Jurnal Emba, 2019), Volume 7 No.1, Halaman : 31 $-40$

${ }^{11}$ Kurniawati, Ely, Pengaruh Budaya Organisasi dan Iklim Organisasi terhadap Kinerja Pegawai. (Dimensi,2018), Volume 7, No. 2, Halaman : 240-254

${ }^{12}$ Susanti, Fahmi, Pengaruh Budaya Organisasi, dan Displin Kerja, terhadap Kinerja Karyawan pada Klinik Tumbuh Kembang Yamet Pamulang (Jurnal Ilmiah, Manajemen Sumber Daya Manusia. Jenius, 2019), Volume 2, No. 2

${ }^{13}$ Ibid., hlm 2

${ }^{14}$ Purba, Deni Candra., Lengkong, Victor P.K., Loindong ,Sjendry, Analisis Pengaruh Kepuasan Kerja, Motivasi Kerja dan Disiplin Kerja terhadap Kinerja Karyawan pada Perusahaan Umum
} 
yang menyatakan bahwa kepuasan kerja berpengaruh positif dan signifikan terhadap kinerja yang artinya semakin meningkat kepuasan kerja seorang karyawan maka semakin meningkat pula kinerja karyawan tersebut.

\section{Pengaruh Budaya Organisasi terhadap Kinerja Karyawan Melalui Kepuasan Kerja}

Budaya organisasi memiliki pengaruh yang sangat kuat terhadap kepuasan kerja dan juga kinerja. Budaya organisasi yang baik akan memberikan semangat bagi karyawan dalam bekerja dan akan memberikan kenyamanan bagi karyawan dalam bekerja sehingga kinerja karyawan dapat meningkat. Kinerja karyawan yang tinggi akan mendorong perusahaan untuk memberikan reward berupa kompensasi yang layak sehingga kepuasan kerja karywan dapat tercapai. Semakin tinggi kepuasan kerja yang dicapai oleh seorang karyawan akan menyebabkan semakin tinggi pula kinerja yang akan dihasilkan oleh karyawan tersebut. Jadi budaya organisasi akan berpengaruh positif terhadap kinerja karyawan melalui kepuasan kerja sesuai dengan penelitian yang telah dilakukan oleh Mustika dan Utomo ${ }^{16}$ yang menyatakan bahwa budaya organisasi berpengaruh tidak langsung terhadap kinerja karyawan, melalui kepuasan kerja

\section{KESIMPULAN}

Budaya organisasi berpengaruh positif terhadap kepuasan kerja, budaya organisasi berpengaruh positif terhadap kinerja karyawan, kepuasan kerja

Percetakan Negara Republik Indonesia Cabang Manado. (Jurnal Emba, 2019) Volume 7 No. 1 Halaman : $841-850$

15 Susanto, Natalia. 2019, Pengaruh Motivasi Kerja, Kepuasan Kerja dan Disiplin Kerja terhadap Kinerja Karyawan pada Divisi Penjualan PT Rembaka. (Agora, 2019) Volume 7 No. 1

16 Mustika, Agnes., Utomo, Hardi. 2013. Pengaruh Budaya Organisasi, Terhadap Kinerja Karyawan Dengan Variabel Kepuasan Kerja Sebagai Variabel Intervening (Studi Kasus Pada Koperasi Simpan Pinjam Gradiska Kecamatan Tuntang Kabupaten Semarang Tahun 2013). (Among Makarti, 2013), Volume 6 No.12 
berpengaruh positif terhadap kinerja karyawan, budaya organisasi berpengaruh positif terhadap kinerja karyawan melalui kepuasan kerja.

\section{Daftar Pustaka}

Fadude ,Fikri Djafar , Tawas, Hendra N, Poluan, Jane Grace. Pengaruh Budaya Organisasi dan Iklim Organisasi terhadap Kinerja Pegawai. Jurnal Emba. Vol.7 No.1 Januari 2019, Hal. 31 - 40

Handoko, T. Hani.2014. Manajemen Personalia dan Sumber Daya Manusia. Yogyakarta: BPFE

Herawan, K., M. D. Mukzam dan G. E. Nurtjahjono. 2015. Pengaruh Budaya Organisasi terhadap Kepuasan Kerja Karyawan, Studi pada PT. Bank Rakyat Indonesia (Persero) Kantor Cabang Kota Malang Kawi. Jurnal Administrasi Bisnis. Volume 1(1), Halaman : $1-6$

Kurniawati, Ely. 2018. Pengaruh Budaya Organisasi dan Iklim Organisasi terhadap Kinerja Pegawai. Dimensi, Vol. 7, No. 2 : 240-254 Juli 2018. Issn: 2085-9996

Mangkunegara, Aa. Anwar Prabu. 2008. Evaluasi Kinerja SDM. Bandung: PT. RefikaAditama

Mangkunegara, Aa. Anwar Prabu. 2008. Manajemen Sumber Daya Manusia Perusahaan. Bandung: Rosda

Mathis, R. L., dan J.H. Jackson. 2006. Manajemen Sumber Daya Manusia. Jakarta: Salemba Empat

Mustika, Agnes., Utomo, Hardi. 2013. Pengaruh Budaya Organisasi, Terhadap Kinerja Karyawan Dengan Variabel Kepuasan Kerja 
Sebagai Variabel Intervening (Studi Kasus Pada Koperasi Simpan Pinjam Gradiska Kecamatan Tuntang Kabupaten Semarang Tahun 2013). Among Makarti Vol.6 No.12, Desember 2013

Prahasti, Shella., Wahyono. 2019. Pengaruh Gaya Kepemimpinan, Budaya Organisasi, dan Lingkungan Kerja terhadap Kinerja Pegawai dengan Kepuasan Kerja Sebagai Mediator. Economic Education Analysis Journal, 7(2), 543-552

Purba, Deni Candra., Lengkong, Victor P.K., Loindong ,Sjendry. 2019. Analisis Pengaruh Kepuasan Kerja, Motivasi Kerja dan Disiplin Kerja terhadap Kinerja Karyawan pada Perusahaan Umum Percetakan Negara Republik Indonesia Cabang Manado. Jurnal Emba Vol.7 No.1 Januari 2019, Hal. 841 - 850

Robbins, Stephen P. 2003. Perilaku Organisasi. Jakarta: PT. Indeks Kelompok Gramedia

Schein, Edgar H. 2004. Organizational Culture and Leadership. San Fransisco : Bass Publishers.

Susanti, Fahmi. 2019. Pengaruh Budaya Organisasi, dan Displin Kerja, terhadap Kinerja Karyawan pada Klinik Tumbuh Kembang Yamet Pamulang. Jurnal Ilmiah, Manajemen Sumber Daya Manusia. Jenius. Vol. 2, No. 2, Januari 2019

Susanto, Natalia. 2019. Pengaruh Motivasi Kerja, Kepuasan Kerja, dan Disiplin Kerja terhadap Kinerja Karyawan pada Divisi Penjualan PT Rembaka. Agora Vol. 7, No. 1 (2019)

Wahyuniardi, Rizki., Nurjaman, Sidik., 2018. Pengaruh Budaya Organisasi 
dan Lingkungan Kerja Terhadap Kepuasan Kerja dan Kinerja Karyawan. Jurnal Optimasi Sistem Industri - Vol. 17 No. 2 (2018) 143-151 